dr n. med. Robert GALĄZKOWSKI ${ }^{1}$

mgr Agata PAWLAK ${ }^{2}$

dr n. med. Konrad PSZCZOLOWSKI ${ }^{3}$

Przyjęty/Accepted/Принята: 04.06.2013;

Zrecenzowany/Reviewed/Рецензирована: 03.06.2014;

Opublikowany/Published/Опубликована: 30.06.2014;

\title{
ROLA JEDNOSTEK KRAJOWEGO SYSTEMU RATOWNICZO-GAŚNICZEGO W FUNKCJONOWANIU SYSTEMU PAŃSTWOWE RATOWNICTWO MEDYCZNE W REJONACH WIEJSKICH W POLSCE
}

\author{
The role of the National Rescue and Firefighting System in the National \\ Emergency Medical System Functioning in Rural Areas in Poland
}

\author{
Роль подразделений Национальной Спасательно-Гасящей Системы \\ в функционировании Государственной Системы Неотложной Медицинской \\ Помощи в сельских районах Польши
}

\begin{abstract}
Abstrakt
Wprowadzenie: Nawet w najlepiej finansowanych i zorganizowanych systemach ratownictwa medycznego czas dotarcia na miejsce zdarzenia bywa zbyt długi, najczęściej na tereny pozamiejskie. Kluczową rolę odgrywają w tej sytuacji osoby umiejące udzielać pierwszej pomocy, zwłaszcza kwalifikowanej. Należy więc dążyć do usprawnienia współdziałania systemu Państwowe Ratownictwo Medyczne (PRM) z Krajowym Systemem Ratowniczo-Gaśniczym (KSRG).

Materiał i metody: Celem pracy było wykonanie analizy działań prawnych i organizacyjnych systemów PRM oraz KSRG w zakresie udzielania pomocy osobom znajdującym się w stanie nagłego zagrożenia zdrowotnego, dokonanie podsumowania potencjału KSRG w zakresie KPP, a także zbadanie za pomocą ankiety opinii pracowników systemu PRM o jakości działań ratowników KSRG w zakresie udzielania KPP. Badaniem objęto grupę 98 pracowników systemu Państwowego Ratownictwa Medycznego, w tym lekarzy systemu, ratowników medycznych i pielęgniarek systemu z obszaru kraju. W badaniu posłużono się metodą sondażu diagnostycznego, wykorzystując anonimową ankietę własnego autorstwa. 22 pytania ankietowe miały na celu zbadanie poziomu udzielania kwalifikowanej pierwszej pomocy przez jednostki KSRG oraz ocenę zaangażowania tych jednostek w udzielanie KPP.

Wyniki: Badania ankietowe, w których pracownicy ZRM ocenili dotychczasową współpracę, wykazały, że w wielu przypadkach zespoły włączone do KSRG, jako pierwsze na miejscu zdarzenia, podejmują właściwe działania, jednak umiejętności strażaków w zakresie KPP wymagają poprawy. Potrzebne są stałe praktyczne ćwiczenia zwłaszcza w zakresie resuscytacji krążeniowo-oddechowej (RKO), aby uzyskać optymalną współpracę OSP i PSP dla uzupełnienia systemu PRM.

Wnioski: Udzielanie przez ratowników KSRG KPP osobom znajdującym się w stanie nagłego zagrożenia zdrowotnego przed przybyciem zespołu ratownictwa medycznego zwiększa szanse na przeżycie pacjentów. Szkolenie ratowników KSRG z zakresu KPP wpływa na podniesienie poziomu merytorycznego przygotowania do udzielania pomocy osobom znajdującym się w stanie nagłego zagrożenia zdrowotnego. Należy wprowadzić regulacje prawne umożliwiające dyspozytorowi medycznemu wykorzystanie potencjału KSRG do udzielania KPP przed przybyciem zespołu ratownictwa medycznego. Należy dopracować wymagania dotyczące zasad utrwalania i okresowej kontroli umiejętności po 66-godzinnym kursie KPP, pomimo określonej przepisami recertyfikacji, która odbywa się w cyklach 3-letnich.
\end{abstract}

\footnotetext{
${ }^{1}$ Zakład Ratownictwa Medycznego Warszawskiego Uniwersytetu Medycznego, ul. Żwirki i Wigury 81a, 02-091 Warszawa/Medical University of Warsaw, Poland; adres e-mail: r.galazkowski@lpr.com.pl; wkład merytoryczny/percentage contribution - 50\%

${ }^{2}$ Dział Ratownictwa Medycznego w SP ZOZ Lotnicze Pogotowie Ratunkowe; 01-934 Warszawa, ul. Księżycowa 5/Polish Medical Air Rescue, Poland; wkład merytoryczny/percentage contribution $-40 \%$

${ }^{3}$ Katedra i Zakład Zdrowia Publicznego Warszawskiego Uniwersytetu Medycznego/Medical University of Warsaw, Poland; wkład merytoryczny/percentage contribution $-10 \%$
} 
Słowa kluczowe: kwalifikowana pierwsza pomoc, współpraca systemów, optymalizacja działań ratowniczych Typ artykulu: artykuł przeglądowy

\begin{abstract}
Introduction: Even in the best funded and organised emergency medical units the time of reaching the scene of an accident by rescue units, especially in rural areas, can be too long. People who can provide first aid, especially qualified first aid (QFA), play a key role in such cases. Thus, we should strive to improve the cooperation between the National Emergency Medical System (NEMS) and the National Rescue and Firefighting System (NRFS).

Materials and methods: The aim of this survey was to analyse the organisational and legal actions of both the NEMS and NRFS systems in the scope of providing the first aid to people in a sudden life threatening situation. What is more, the goals of the survey were to make general conclusions about the potential of the NRFS in the scope of providing QFA and, finally, with the use of the questionnaires, examine the opinions of the NEMS workers on the quality of the QFA provided by NRFS rescuers. A group of 98 workers of the NEMS took part in the survey, including doctors, paramedics and nurses from the whole country. The study involved a diagnostic survey in the form of an anonymous questionnaire of own authorship. There were 22 questions prepared to study the quality of QFA provided by the NRFS units and their engagement in providing help.

Results: Medical rescue units employees rated the foregoing cooperation. The results showed that in many cases the units included in the NRFS, which were first at the scene of an accident, undertook proper actions, but the abilities and skills of fire rescuers in the range of QFA still need some improvement. Constant practical trainings are necessary, especially in the scope of CPR in order to achieve the optimal cooperation of Volunteer Fire Brigade and State Fire Service, which will complement the NEMS.

Conclusions: Providing the QFA by NRFS rescuers to people in a sudden life threatening situation, before reaching the scene of an accident by an emergency medical rescue unit, increases the chance of survival of these patients. The QFA training given to NRFS rescuers improves the essential preparation to provide the aid to people in a sudden life threatening situation. Law regulations that allow the medical dispatcher to use the potential of NRFS units to provide the QFA, before the scene of accident is reached by emergency medical rescuers. Furthermore, the requirements for the rules of perpetuation and periodical control of skills after 66 hour of QFA course should be improved, despite the legally regulated recertification, which is held in a 3-year cycle.
\end{abstract}

Keywords: the qualified first aid, systems coordination, optimization of rescue operations Type of article: review article

\title{
Аннотация
}

Введение: Даже в наиболее успешно финансированных и организованных системах неотложной медицинской помощи время приезда на место происшествия бывает слишком долгое, чаще всего касается это загородных территорий. В такой ситуации ключевую роль имеют люди, которые умеют оказать первую помощь, особенно квалифицированную. Следовательно, надо стремиться к улучшению сотрудничества между Государственной Системой Неотложной Медицинской Помощи (PRM) и Национальной Спасательно-Гасящей Системой (KSRG).

Материал и методы: Цель данной работы заключалась в проведении анализа правовых и организационных действий систем PRM и KSRG по предоставлению помощи людям находящимся в состоянии внезапно возникшей угрозы здоровью; обзоре потенциала KSRG в области проведения квалифицированной первой помощи; а также исследовании с помощью опроса мнения сотрудников системы PRM о качестве выполнения спасательных работ спасателями KSRG в сфере предоставления квалифицированной первой помощи. В исследовании приняло участие 98 сотрудников системы PRM, в том числе врачи, фельдшера системы и медсестры системы с территории страны. В исследовании был использован метод диагностического обследования с помощью анонимной анкеты собственного авторства. 22 анкетных вопроса были разработаны с целью изучения уровня предоставления квалифицированной первой помощи подразделениями KSRG и проведения оценкн ангажирования этих подразделений в предоставлении квалифицированной первой помощи.

Результаты: Анкетные исследования, в которых сотрудники ZRM оценивали существующее сотрудничество показали, что во многих случаях команды включёеные в KSRG, как первые на месте происшествия, принимают соответствующие меры, но практические умения пожарных в области первой медицинской помощи нуждаются в улучшении. Необходимы постоянные практические упражнения, особенно в области сердечно-легочной реанимации (RKO) для достижения оптимального сотрудничества Добровольной пожарной службы (OSP) и Государственной пожарной службы (PSP), чтобы усовершенствовать систему PRM.

Выводы: Предоставление спасателями KSRG первой помощи, лицам в состоянии внезапной угрозы здоровью до приезда медицинской спасательной команды увеличивает шансы больных на выживание. Обучение спасателей KSRG в области квалифицированной первой помощи повышает уровень основной подготовки к предоставлению помощи человеку находящемуся в состоянии внезапной угрозы здоровью. Следует ввести правовые регулирования, позволяющие диспетчерам использовать потенциал KSRG для предоставления квалифицированной первой помощи до приезда медицинско-спасательной команды. Надо усовершенствовать требования по закреплению знаний, и их периодических проверок после 66-часового курса квалифицированной первой помощи, несмотря на установленную законом повторную сертификацию, которая проходит каждые 3 года.

Вид статьи: обзорная статья

Ключевые слова: квалифицированная первая помощь, сотрудничество систем, оптимизация спасательных действий 


\section{Cel pracy}

Celem pracy jest analiza działań prawnych i organizacyjnych systemów PRM oraz KSRG w zakresie udzielania pomocy osobom znajdującym się $\mathrm{w}$ stanie nagłego zagrożenia zdrowotnego, dokonanie podsumowania potencjału KSRG w zakresie KPP, a także zbadanie za pomocą ankiety opinii pracowników systemu PRM na temat jakości działań ratowników KSRG w zakresie udzielania KPP.

\section{Material i metody}

Badaniem objęto grupę 98 pracowników systemu Państwowe Ratownictwo Medyczne w tym lekarzy systemu, ratowników medycznych i pielęgniarek systemu z całego kraju. Ankieta była umieszczona w Internecie. Badanie wykonano w okresie od marca do kwietnia 2013 roku. W badaniu posłużono się metodą sondażu diagnostycznego, wykorzystując anonimową ankietę. 22 pytania ankietowe miały na celu zbadanie poziomu udzielania kwalifikowanej pierwszej pomocy przez jednostki KSRG oraz ocenę zaangażowania tych jednostek w udzielanie KPP. Analiza wyników miała stanowić realizację celu pracy. Do obliczeń statystycznych użyto programu Microsoft Office Excel 2007.

\section{Wstęp}

Ratownictwo medyczne jako system organizacyjny ukierunkowane jest przede wszystkim na udzielanie pomocy medycznej osobom znajdującym się w stanie nagłego zagrożenia zdrowotnego. Działania te wykonywane są przez jednostki systemu ratownictwa medycznego, a więc: naziemne zespoły ratownictwa medycznego, lotnicze zespoły ratownictwa medycznego oraz szpitalne oddziały ratunkowe i centra urazowe.

Dla utrzymania efektywności systemu niezbędna jest ciąła kontrola jakości. W tym celu przeprowadzane są liczne badania, których wyniki stanowią podstawę do poprawy organizacji i funkcjonowania działan. System jako struktura dynamiczna ulega ciagłym zmianom, m.in. przez rozszerzanie swoich możliwości dzięki współpracy z jednostkami krajowego systemu ratowniczo-gaśniczego. Kadra pozostających w stałej gotowości ratowników KSRG dysponuje standaryzowanym wyposażeniem i jest jednolicie przeszkolona do udzielania kwalifikowanej pierwszej pomocy.

Odpowiednio zorganizowane współdziałanie systemów, dodatkowo wsparte powszechną znajomością udzielania pierwszej pomocy, może realnie zwiększać szanse osób poszkodowanych na przeżycie i wyzdrowienie. Dyskusja nad organizacją najskuteczniejszej pomocy medycznej osobom znajdującym się w stanie nagłego zagrożenia zdrowotnego trwa od wielu lat. Systemy ratownicze na świecie podlegają ciagłej analizie i modyfikacji, różniąc się w zależności od obowiązujących w danym kraju regulacji prawnych. W ujęciu planistycznym i organizacyjnym w większości opierają się jednak na tak zwanym schemacie „Łańcucha przeżycia” [7].

„Łańcuch przeżycia” ukazuje optymalny układ kolejnych ogniw działań ratunkowych, w tym pierwszą pomoc, elementy medyczne i transport specjalistyczny. Ich efektem finalnym powinno być dostarczenie do szpitalnego oddziału ratunkowego (SOR) osoby, która znalazła się w stanie nagłego zagrożenia zdrowotnego. W wymiarze systemowym elementy te są realizowane przez państwo za pomocą jego służb i poszczególnych podmiotów ratowniczych. Wytyczone są również działania obywatela/świadka zdarzenia w zakresie powiadamiania o nagłym zdarzeniu oraz samej pierwszej pomocy. Obecny stan organizacyjno-prawny polskiego systemu ratownictwa pozwala na skuteczną realizację założeń schematu „łańcucha przeżycia”, co nie znaczy, że nie powinien on podlegać dalszym usprawnieniom.

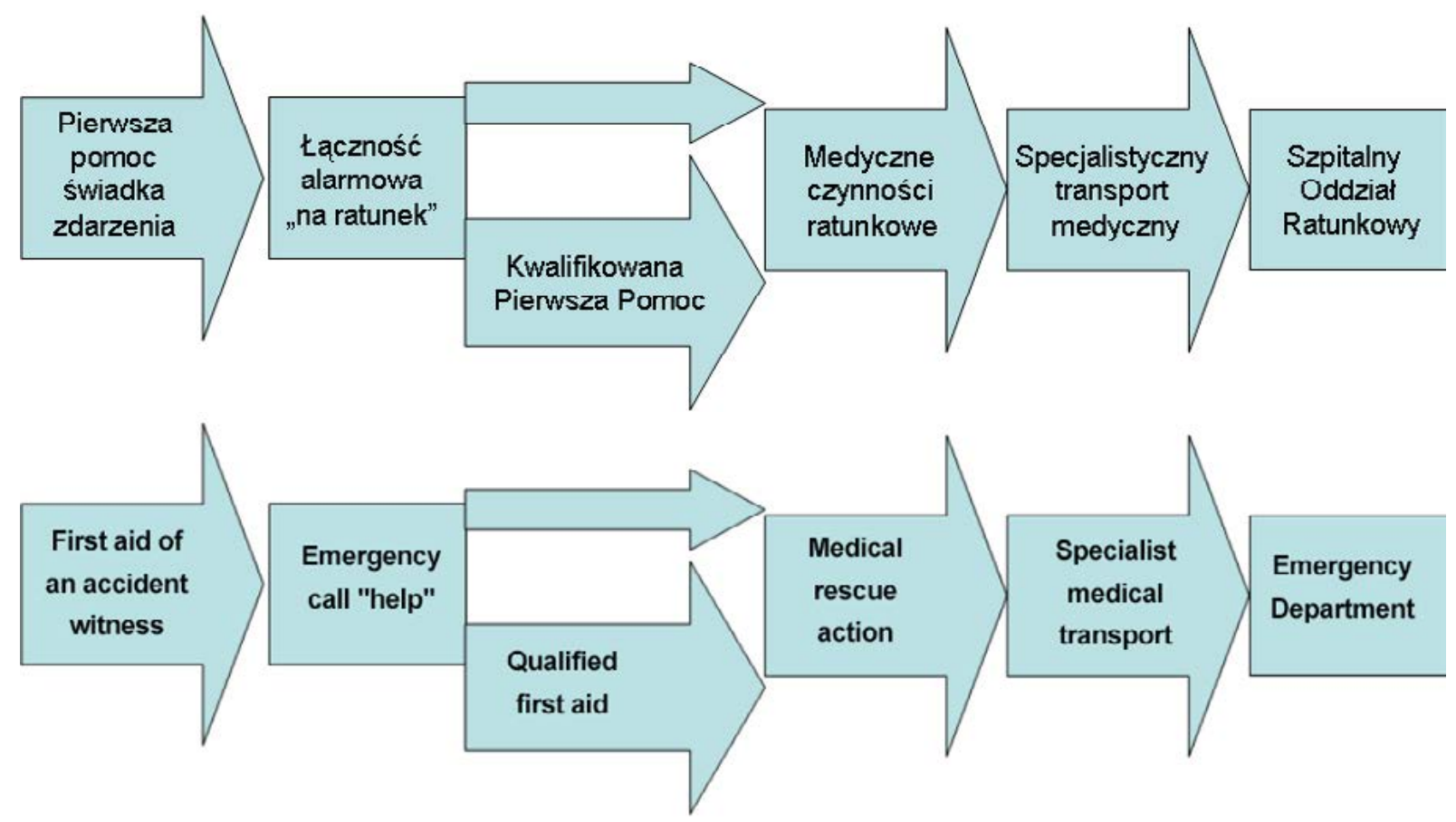

Ryc. 1. Schemat łańcucha przeżycia

Fig. 1. The chain of survival diagram 
W strukturach systemu Państwowe Ratownictwo Medyczne w Polsce funkcjonuje: 14 centrów urazowych, 207 szpitalnych oddziałów ratunkowych, 1450 zespołów ratownictwa medycznego, 17 baz stałych i jedna baza sezonowa Śmigłowcowej Służby Ratownictwa Medycznego, w których stacjonuja lotnicze zespoły ratownictwa medycznego. W wojewódzkich planach działania systemu określona jest również sieć szpitali wyspecjalizowanych w zakresie usług medycznych niezbędnych dla potrzeb ratownictwa medycznego oraz jednostek współpracujących z systemem. W przepisach prawa polskiego określono zadania świadka zdarzenia. Przygotowano wytyczne, na podstawie których planowana jest lokalizacja zespołów ratownictwa medycznego. Analizowane są ich minimalne i maksymalne czasy dotarcia do miejsca zdarzenia. W wyniku przeprowadzanych analiz zmienia się miejsce wyczekiwania zespołu ratownictwa medycznego, czyli prowadzony jest faktyczny nadzór nad funkcjonowaniem systemu na terenie danego województwa. Trwają prace nad udoskonaleniem systemów powiadamiania ratunkowego i łączności.

Pomimo tych działań i stosunkowo dużej liczby zakontraktowanych w Polsce zespołów ratownictwa medycznego, nie zawsze możliwe jest szybkie udzielenie pomocy przez zawodowych ratowników medycznych. Taka sytuacja to nie tylko problem polski. Nawet w najbogatszych krajach świata, zwłaszcza na terenach wiejskich, słabiej zaludnionych zdarza się, że karetka dociera do poszkodowanego później niż po upływie 4-5 minut. To właśnie jest czas, w którym w przypadku zatrzymania akcji serca należy podjąć działania resuscytacyjne. Może je skutecznie prowadzić każdy, kto został w tym zakresie przeszkolony, podtrzymując podstawowe czynności życiowe osoby ratowanej do czasu przybycia pomocy medycznej. Zatem warunkiem zapewnienia jak najszybszej pomocy osobom znajdującym się w stanie nagłego zagrożenia zdrowotnego jest powszechne nauczanie zasad pierwszej pomocy.

Można również wykorzystać jak najlepiej potencjał innych służb ratowniczych (niemedycznych) przygotowanych już do udzielania tzw. kwalifikowanej pierwszej pomocy. Należy w tym celu zmodyfikować istniejące procedury i regulacje prawne. Niniejsza praca wykazuje potrzebę i możliwość sformalizowania włączania innych służb ratowniczych, np. jednostek KSRG, w udzielanie pomocy osobom w stanie nagłego zagrożenia zdrowotnego, zwłaszcza na obszarach wiejskich. Nad takimi rozwiązaniami od lat dyskutuje się, realizuje się je i doskonali w różnych krajach $[6,9,2]$.

W Polsce oprócz systemu Państwowe Ratownictwo Medyczne funkcjonuje również krajowy system ratowniczo-gaśniczy powołany na mocy rozporządzenia Ministra Spraw Wewnętrznych i Administracji. Tworzą go między innymi jednostki zawodowe Państwowej Straży Pożarnej oraz jednostki Ochotniczych Straży Pożarnych. Jednym z zadań KSRG opisanych w rozporządzeniu jest: dotarcie i wykonanie dostępu do zagrożonych lub poszkodowanych osób wraz z udzieleniem im kwalifikowanej pierwszej pomocy i ewakuacją poza strefę zagrożenia [8].
Pojęcie i zakres KPP zostały zdefiniowane w ustawie $\mathrm{z}$ dnia 8 września 2006 roku o Państwowym Ratownictwie Medycznym. Kwalifikowana pierwsza pomoc to czynności podejmowane przez ratownika wobec osoby w stanie nagłego zagrożenia zdrowotnego. Ratownikiem może być osoba, która posiada pełną zdolność do czynności prawnych, będąca członkiem, zatrudniona lub pełniąca służbę w jednostkach współpracujących z systemem, posiadająca ważne zaświadczenie o ukończeniu kursu w zakresie KPP i uzyskaniu tytułu ratownika, której stan zdrowia pozwala na udzielanie KPP [12]. Wśród jednostek współpracujących z systemem, które zostały zdefiniowane w ustawie, sa jednostki zawodowe PSP oraz jednostki OSP włączone do KSRG.

Zadania, które w ramach KPP może wykonywać ratownik, obejmują następujący zakres: resuscytację krążeniowo-oddechową, bezprzyrządową i przyrządową, z podaniem tlenu oraz zastosowaniem według wskazań defibrylatora zautomatyzowanego; tamowanie krwotoków zewnętrznych i opatrywanie ran; unieruchamianie złamań i podejrzeń złamań kości oraz zwichnięć; ochronę przed wychłodzeniem lub przegrzaniem; prowadzenie wstępnego postępowania przeciwwstrząsowego; ochronę termiczną; stosowanie tlenoterapii biernej; ewakuację z miejsca zdarzenia; wsparcie psychiczne oraz prowadzenie wstępnej segregacji medycznej [12].

Jak najszybsze rozpoczęcie udzielania pierwszej pomocy przez świadka nagłego zdarzenia lub wdrożenie czynności z zakresu KPP przez jednostki współpracujące $\mathrm{z}$ systemem obecne przed przybyciem zespołu ratownictwa medycznego mogą ponad wszelką wątpliwość przyczynić się do poprawy skuteczności medycznych czynności ratunkowych, udzielanych osobie znajdującej się w stanie nagłego zagrożenia zdrowotnego.

Biorąc pod uwagę szerszy niż w pierwszej pomocy zakres kompetencji KPP udzielony ratownikom oraz potrzebę utrzymania na wysokim poziomie wiedzy i umiejętności ratowników, ustawodawca szczegółowo określił zasady przeprowadzania kursu z zakresu KPP, opisując wymogi organizacyjne i sprzętowe dla podmiotów realizujących szkolenia, skład osobowy komisji egzaminacyjnej, zasady przeprowadzania egzaminu, a także wzór zaświadczenia o ukończeniu kursu i zdaniu egzaminu. Określono również szczegółowy plan nauczania KPP, który został wypracowany przez ekspertów i zamieszczony w rozporządzeniu Ministra Zdrowia.

Z danych statycznych Komendy Głównej PSP na 2013 rok stan osobowy wyszkolenia w zakresie KPP strażaków włączonych do KSRG wynosi ok. 6800 strażaków PSP oraz ok. 2500 strażaków OSP (ważności szkolenia 2013 rok, wg danych SWDST na dzień 18.03.2013 r.). Obecnie działania KPP realizują wszystkie jednostki ratowniczo-gaśnicze (zawodowe) PSP oraz jednostki ochrony przeciwpożarowej OSP, włączone do KSRG, posiadające gotowość operacyjną do podjęcia działań ratownictwa medycznego przez co najmniej dwóch ratowników (w rozumieniu ustawy o PRM) w składzie zastępu ratowniczego [14]. Docelowo zdolność do podjęcia działań w zakresie KPP mają mieć wszyscy strażacy wszystkich jednostek KSRG. 
W zakresie organizacji KSRG w ostatnich latach przyjęto kilka istotnych założeń. Wśród nich takie, że dla każdej jednostki KSRG utrzymującej gotowość do podjęcia działań ratowniczych z zakresu KPP ustalono obszar chroniony - zdefiniowany jako obszar niezależny od podziału administracyjnego kraju i PSP, w którym dana jednostka podejmie działanie ratownicze, w czasie do $15 \mathrm{~min}$, $20 \mathrm{~min}, 25 \mathrm{~min}$ i do $30 \mathrm{~min}$, zależnie od rodzaju poziomu gotowości, określając tym samym dostępność jednostek KSRG dla potrzeb współpracy z jednostkami systemu PRM. Określono szczegółowo 3 poziomy gotowości - A, B, C. Zależnie od poziomu gotowości opracowano minimalny standard wyposażenia dla jednostki OSP włączonej do KSRG, który zakłada między innymi posiadanie przez taką jednostkę zestawu ratunkowego PSP-R1. Jednocześnie dla każdego poziomu gotowości określono standard osobowy. Przy podstawowym poziomie gotowości typu A przyjęto, że jednostka OSP włączona do KSRG musi posiadać co najmniej 8 ratowników z przeszkoleniem w zakresie KPP, w tym przynajmniej 2 ratowników może podjąć interwencję w czasie nie dłuższym niż 15 minut (z prawdopodobieństwem 80\%) [15].

Aktualnie w zakresie wyposażenia ratownictwa medycznego, zgodnie z Zasadami organizacji ratownictwa medycznego w krajowym systemie ratowniczo-gaśniczym [15], obowiązuje zestaw ratownictwa medycznego R1, respirator transportowy dla grup specjalistycznych oraz zautomatyzowane defibrylatory (AED). Na ryc. 2 przedstawiono liczbę zestawów ratownictwa medycznego w jednostkach KSRG będących na wyposażeniu do 2013 roku. Zestawy te różniły się między sobą zawartością. Podstawowym rodzajem wyposażenia był zestaw PSPR1 i stanowił zdecydowaną większość - 87,25\% wyposażenia jednostek KSRG. Z danych PSP wynika, iż istniały również zestawy rozszerzone i specjalistyczne: inne, PSP-R0, PSP-R2, PSP-R3 [3].

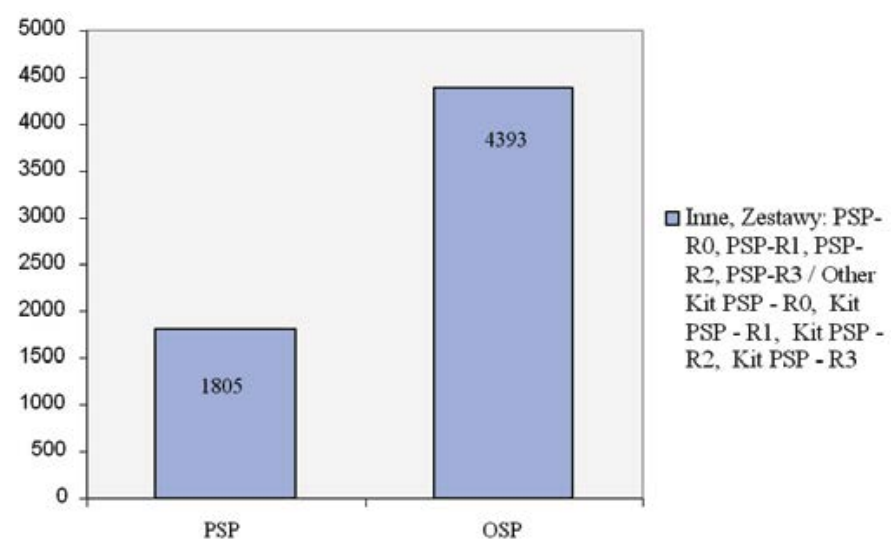

Ryc. 2. Liczba zestawów ratownictwa medycznego w jednostkach KSRG wg danych SWDST na dzień 18.03.2013 r. [3]

Fig. 2. The number of first aid sets in NRFS units according to the data Decision Support System-ST as for March 18, 2013 [3]

W trakcie dalszej analizy współpracy jednostek KSRG z systemem PRM w rejonach wiejskich w Polsce nie sposób pominąć danych liczbowych, które wskazują zwyżkową tendencję włączania jednostek OSP do KSRG oraz ukazuja potencjał sprzętowy i ludzki, jakim dziś dysponuje KSRG [1]. W 2013 roku system KSRG skupiał 500 JRG PSP oraz 3916 jednostek OSP [13].

Liczba zdarzeń, $z$ udziałem tylko PSP lub OSP włączonych do KSRG, w latach 2006-2012 oscylowała na poziomie 350-411 tys. (ryc. 4. Ogólna liczba zdarzeń z udziałem tylko PSP lub OSP w KSRG) [3].

Liczba osób poszkodowanych w tych zdarzeniach stale rośnie niezależnie od liczby samych zdarzeń. Liczba osób, którym udzielona została „pomoc medyczna” (według nomenklatury statystycznej PSP) przez różne służby porządku i bezpieczeństwa publicznego, w 2012 roku wyniosła już ponad 51 tys. przypadków. Porównując to $\mathrm{z}$ danymi o liczbie osób, którym udzielona została pomoc

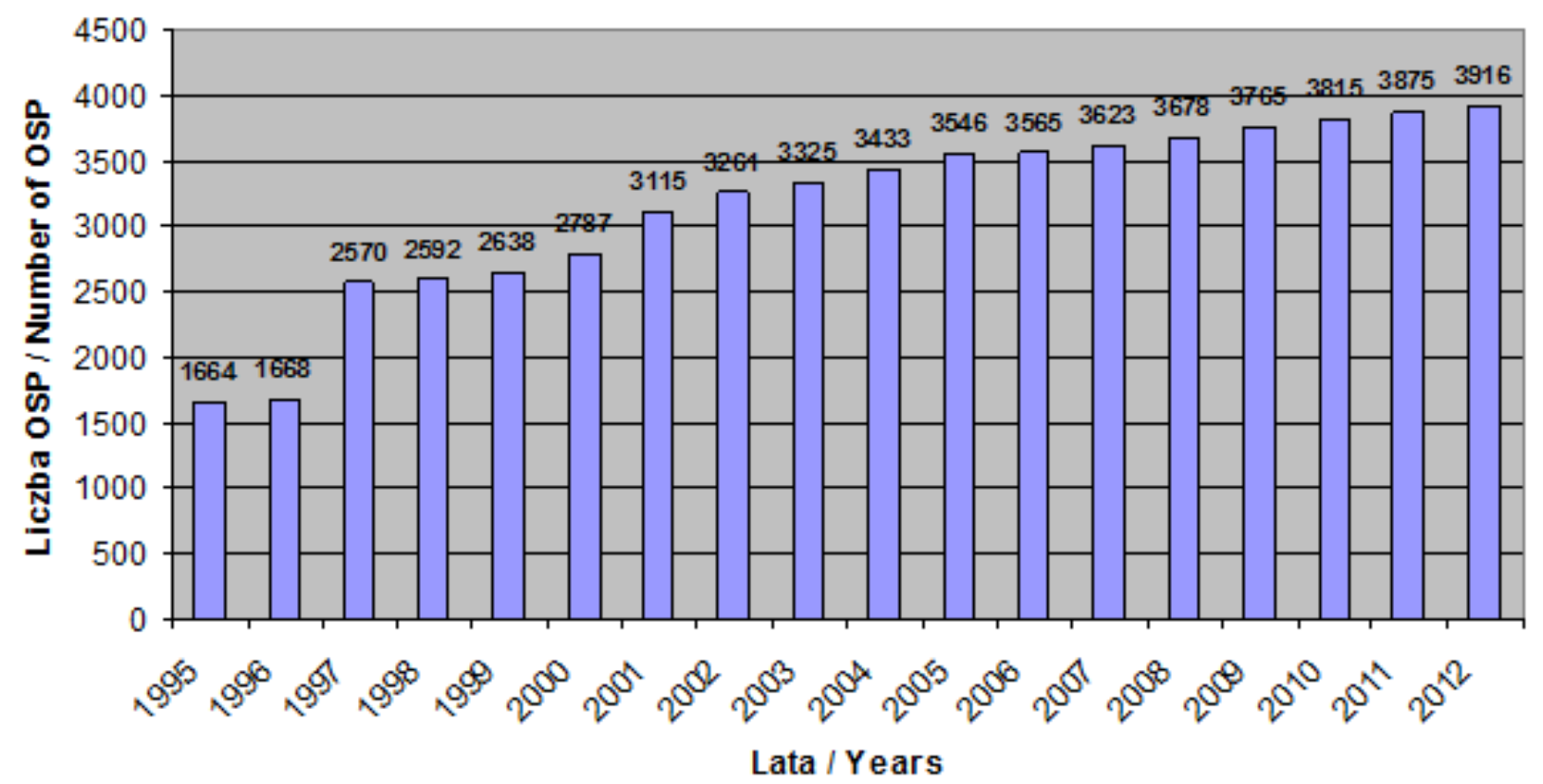

Ryc. 3. Stan jednostek OSP włączonych do KSRG w latach 1995-2012

Fig. 3. Volunteer Firefighting Units included in NRFS in 1995-2012 


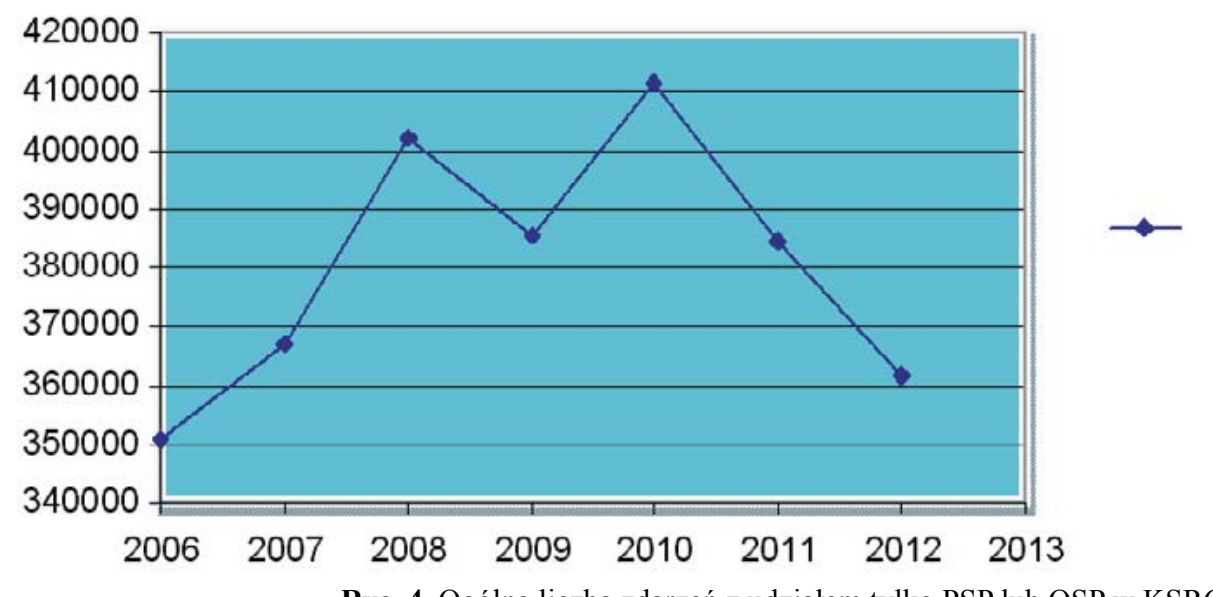

Ogółem zdarzeń (bez fałszywych)/ The total number of events (no false events)

Ryc. 4. Ogólna liczba zdarzeń z udziałem tylko PSP lub OSP w KSRG

Fig. 4. Total number of accidents with only SFS or VFU participation, in NRFS

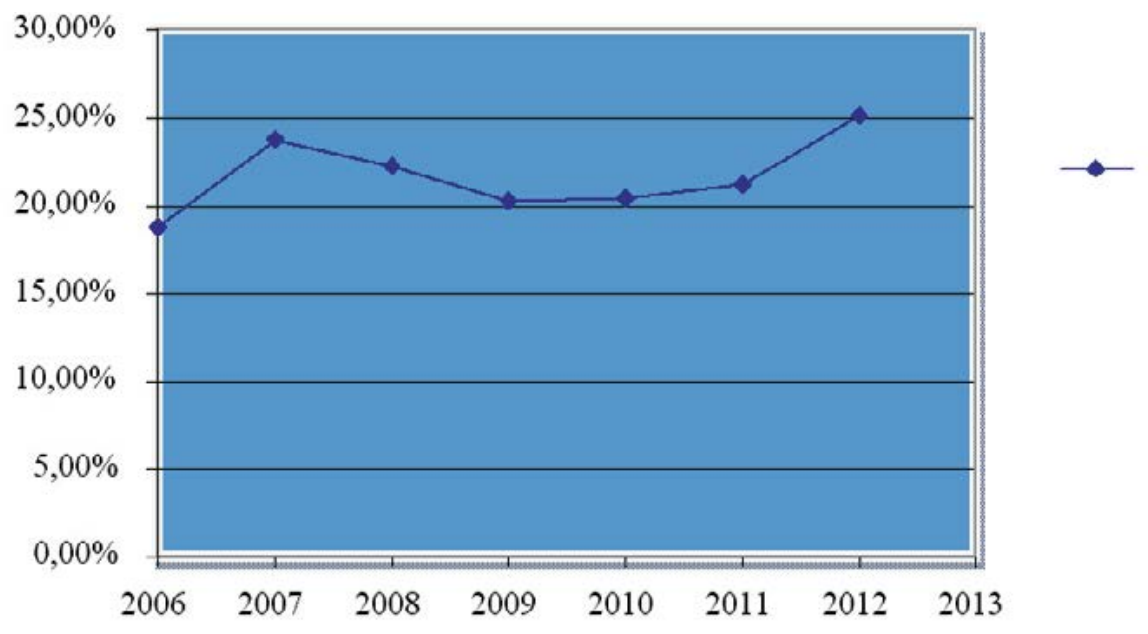

Udział procentowy udzielonej pomocy przez starażaków względem udzielonej pomocy medycznej na terenie akcji / The percentage of the medial assistance provided by firefighters at the scene

Ryc. 5. Pomoc medyczna udzielona przez strażaków

Fig. 5. First aid provided by the firefighters

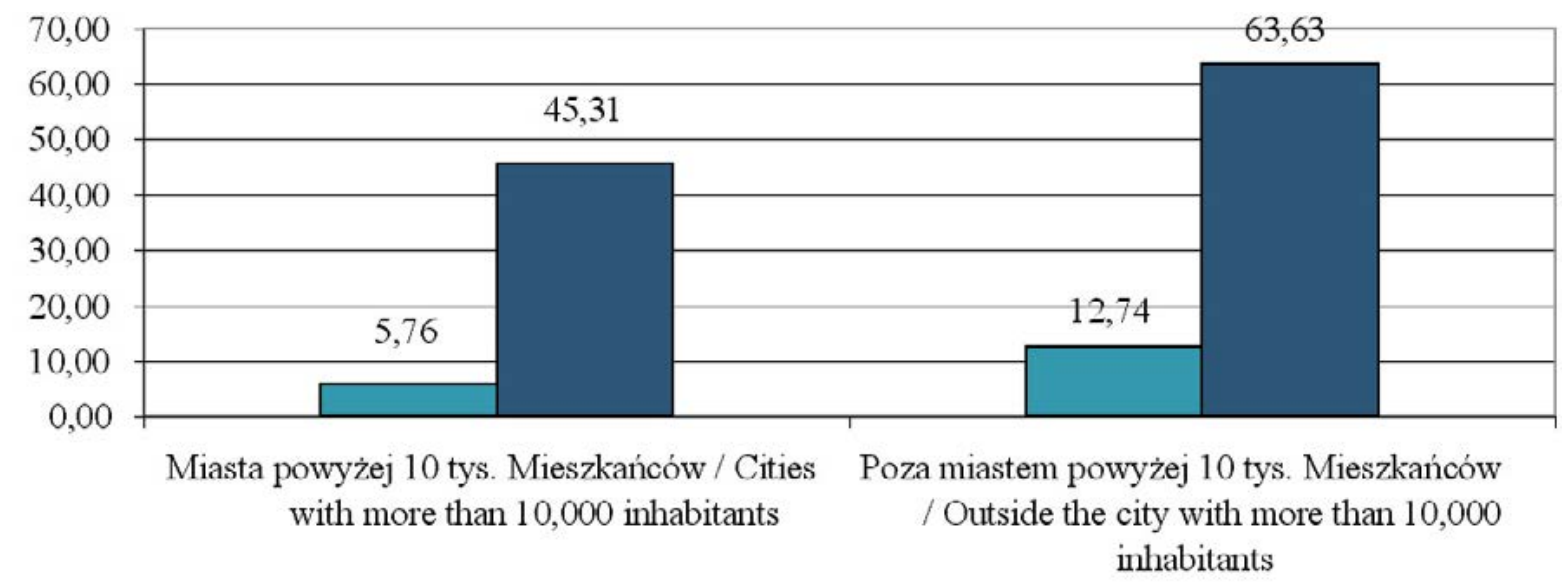

Mediana czasu dotarcia zespołów na miejsce zdarzenia (min) /

Average time that takes a medical rescue unit to arrive at the scene (in minutes)

Maksymalny średni czas dotarcia zespołów na miejsce zdarzenia (min) /

The maximum average time that takes a medical rescue unit to arrive at the scene (in minutes)

Ryc. 6. Czasy dotarcia ZRM w Polsce w 2011 roku

Fig. 6. The arrival time of Medical Rescue Units in 2011 
przez samych strażaków włączonych do KSRG, można spostrzec wysoką i stałą tendencję wzrostową na średnim poziomie powyżej 21\% (Ryc. 5. Pomoc medyczna udzielona przez strażaków) [3]. Średni czas dotarcia do zdarzenia w 2012 roku przez jednostki PSP i OSP w KSRG wynosił 6,18 minuty [3].

Liczba zespołów ratownictwa medycznego (ZRM) w 2011 roku w Polsce wynosiła średnio 1448,47. W tym czasie ZRM zrealizowały blisko 3 mln wyjazdów, w tym ponad $80 \%$ do stanów nagłego zagrożenia zdrowotnego [4]. Dodatkowo w 2011 roku lotnicze zespoły ratownictwa medycznego zrealizowały loty ratownicze do 7311 pacjentów [5].

Dla pogotowia ratunkowego w 2011 roku mediana czasu dotarcia ZRM na miejsce zdarzenia w Polsce wynosiła dla miast powyżej 10 tys. mieszkańców 5,76 minuty zaś poza miastami powyżej 10 tys. mieszkańców 12,74 minuty (ryc. 6. czasy dotarcia ZRM w Polsce w 2011 roku) [4]. Są to wyjazdy zespołów ratownictwa medycznego, licząc od chwili przyjęcia zgłoszenia przez dyspozytora medycznego do przybycia zespołu ratownictwa medycznego na miejsce zdarzenia.

\section{Wyniki}

$\mathrm{Na}$ potrzeby oceny roli jednostek włączonych do KSRG została opracowana przez autorów ankieta internetowa „Współpraca jednostek KSRG z systemem PRM”. Ankieta skierowana była do pracowników zespołów ratownictwa medycznego - lekarzy systemu, pielęgniarek systemu oraz ratowników medycznych. Najliczniejsza grupa zawodowa, która wzięła udział $\mathrm{w}$ badaniu, to ratownicy medyczni - 69,39\%. Celem przeprowadzenia ankiety była próba zbadania poziomu udzielania KPP przez jednostki KSRG oraz próba oceny zaangażowania jednostek KSRG w udzielanie KPP. Liczba respondentów wyniosła 98 osób.

Do wypełnienia ankiety przystąpiły osoby z każdego województwa Polski. Największy odsetek (29,59\% respondentów) to pracownicy ochrony zdrowia $\mathrm{z}$ województwa mazowieckiego (głównie Warszawa i okolice: powiat warszawski zachodni, Legionowo, Grodzisk Mazowiecki oraz Płock).

W pytaniu 4 ankiety zapytano o to, jak często przed przyjazdem ZRM jednostka KSRG jest już na miejscu zdarzenia. Ponad połowa ankietowanych wskazała, że często, a 1/5, że bardzo często.

Tabela 1.

Pytania i odpowiedzi do ankiety - pytanie nr 4

Table 1.

The survey questions and answers - question no. 4

4. Jak często przed przyjazdem ZRM, którego jesteś członkiem, jednostka KSRG jest już na miejscu? / How often before the arrival of your MRU unit, is the NRFS unit already at the scene?

\begin{tabular}{|c|c|}
\hline Odpowiedzi /Answers & Liczba / Number \\
\hline 1 - wcale / not at all & 1 \\
\hline - bardzo rzadko / very rarely & 9 \\
\hline 4 - rzadko / rarely & 15 \\
\hline 5 - bardzęto / often & 53 \\
\hline 6 - zawsęsto / very often & 20 \\
\hline
\end{tabular}

W pytaniach od 5 do 8 zawarto oceny zaangażowania jednostek KSRG w KPP oraz w pomoc ZRM (tabela $\mathrm{nr} 2$ ).

Według sześciostopniowej skali 46,39\% osób uznało, że jednostka KSRG będąca na miejscu zdarzenia przed przybyciem ZRM często (odp. 4) podejmuje jakiekolwiek czynności w zakresie KPP. 1/4 stwierdziła, że rzadko, bardzo rzadko i wcale (odp. 3, 2, 1), więcej, bo 28,87\% osób uznało, że bardzo często i zawsze (odp. 5, 6).

W przypadku pomocy zespołowi RM w udzielaniu medycznych czynności ratunkowych prawie 30\% osób stwierdziło, że następuje to zawsze (odp. 6). Zdecydowanie najwyżej zaangażowanie straży pożarnej oceniane jest przy pomocy w transporcie pacjenta do karetki/śmigłowca - prawie $45 \%$ ankietowanych uważa, że zawsze (odp. 6), a 38,14\%, że bardzo często (odp. 5).

$44,33 \%$ respondentów uznało, że jednostki włączone do KSRG zawsze (odp. 6) wymieniaja deski ortopedyczne z ZRM (w przypadku użycia swojej dla pacjenta), stosując tym samym zasadę, jednych noszy".

Tabela 2.

Pytania i odpowiedzi do ankiety - od pytania 5 do 8

Table 2.

The survey questions and answers -questions 5-8

5. Jak często jednostka KSRG będąca na miejscu zdarzenia przed przybyciem ZRM, którego jesteś członkiem, podejmuje jakiekolwiek czynności w zakresie KPP? / How often does the NRFS unit present at the scene before the arrival of your MRU team take any of the actions related to qualified first aid?

Uwagi: jeżeli w pytaniu 4 zaznaczyłaś (-eś) odpowiedź 1 zaznacz odpowiedź ND (nie dotyczy) / Note: If in question 4 you have selected the answer 1 - select the answer NA (not applicable)

\begin{tabular}{|c|c|}
\hline Odpowiedzi / Answers & Liczba / Number \\
\hline 1 - wcale / not at all & 2 \\
\hline - bardzo rzadko / very rarely & 9 \\
\hline - rzadko / rarely & 13 \\
\hline 4 - często / often & 45 \\
\hline 5 -bardzo często / very often & 16 \\
\hline 6 - zawsze / always & 12 \\
\hline ND / NA - nie dotyczy / not & 1 \\
\hline applicable & \\
\hline
\end{tabular}

6. Jak często jednostka KSRG będąca na miejscu zdarzenia pomaga zespołowi ZRM, którego jesteś członkiem, w medycznych czynnościach ratunkowych? / How often does the NRFS unit present at the scene help the MRU team, which you belong to, in providing emergency medical operations?

Uwagi: jeżeli w pytaniu 4 zaznaczyłaś (-eś) odpowiedź 1 zaznacz odpowiedź ND (nie dotyczy) / Note: If in question 4 you have selected answer 1 - select the answer NA (not applicable)

\section{Odpowiedzi / Answers Liczba / Number}

\begin{tabular}{|c|c|}
\hline 1 - wcale / not at all & 4 \\
\hline 2 - bardzo rzadko / very rarely & 5 \\
\hline 3 - rzadko / rarely & 12 \\
\hline 4 - często / often & 26 \\
\hline 5 -bardzo często / very often & 21 \\
\hline 6 - zawsze / always & 29 \\
\hline ND / NA- nie dotyczy / not applicable & 1 \\
\hline
\end{tabular}


7. Jak często jednostka KSRG będąca na miejscu zdarzenia pomaga ZRM, którego jesteś członkiem, w transporcie pacjenta do karetki/śmigłowca? / How often does the NFRS unit which is on the scene help your MRU team to transport a patient to the ambulance or helicopter?

Uwagi: jeżeli w pytaniu 4 zaznaczyłaś (-eś) odpowiedź 1 zaznacz odpowiedź ND (nie dotyczy) / Note: If in question 4 you have selected answer 1, select the answer NA (not applicable)

\begin{tabular}{|c|c|}
\hline Odpowiedzi / Answers & Liczba / Number \\
\hline 1- wcale / not at all & 1 \\
\hline 2- bardzo rzadko / very rarely & 1 \\
\hline 3- rzadko / rarely & 2 \\
\hline 4- często / often & 13 \\
\hline 5-bardzo często / very often & 37 \\
\hline 6- zawsze / always & 43 \\
\hline
\end{tabular}

ND / NA- nie dotyczy / not applicable

8. Jak często jednostka KSRG będąca na miejscu zdarzenia wymienia sprzęt medyczny taki jak deska ortopedyczna z ZRM, którego jesteś członkiem, w przypadku użycia swojej deski przez jednostkę KSRG dla pacjenta, stosując tym samym zasade , jednych noszy"? / How often does the NRFS unit, being at the scene exchange medical equipment e.g. an orthopedic board with your MRU team, when using their board for the patient, applying thereby the principle of "one stretcher"?

Uwagi: jeżeli w pytaniu 4 zaznaczyłaś (-eś) odpowiedź 1 zaznacz odpowiedź ND (nie dotyczy) / Note: If in question 4 you have selected answer 1 - select the answer NA (not applicable)

\begin{tabular}{|c|c|}
\hline Odpowiedzi / Answers & Liczba / Number \\
\hline 1- wcale / not at all & 8 \\
\hline 2- bardzo rzadko / very rarely & 3 \\
\hline 3- rzadko / rarely & 3 \\
\hline 4- często / often & 27 \\
\hline 5-bardzo często / very often & 13 \\
\hline 6- zawsze / always & 43 \\
\hline ND / NA- nie dotyczy / not applicable & 1 \\
\hline
\end{tabular}

Kolejne pytania ankiety dotyczyły realizacji podstawowych czynności z zakresu KPP, realizowanych przez ratowników jednostek KSRG wraz z próbą oceny jakości ich wykonania (tabela 3).

Tabela 3.

Pytania i odpowiedzi do ankiety - od 9 do 16 pytania

Table 3.

The survey questions and answers - questions 9-16

Jak często jednostka KSRG podejmująca czynności w zakresie KPP na miejscu zdarzenia przed przyjazdem ZRM, którego jesteś członkiem wykonuje u pacjenta udrożnienie dróg oddechowych? / How often does the NRFS unit undertake first medial aid action at the scene before the arrival of the MRU you belong to and clear the patient's airway?

Uwagi: jeżeli w pytaniu 4 lub 5 zaznaczyłaś (-eś) odpowiedź 1 - zaznacz odpowiedź ND (nie dotyczy) / Note: If in questions 4 or 5 you have selected answer 1 - select answer NA (not applicable)

\begin{tabular}{|c|c|}
\hline Odpowiedzi / Answers & Liczba / Number \\
\hline 1- wcale / not at all & 3 \\
\hline 2- bardzo rzadko / very rarely & 22 \\
\hline 3- rzadko / rarely & 28 \\
\hline 4- często / often & 24 \\
\hline 5-bardzo często / very often & 12 \\
\hline
\end{tabular}

6- zawsze / always 6

ND / NA- nie dotyczy / not applicable 3

10. Jak oceniasz poziom wykonywanych czynności KPP przez jednostkę KSRG w zakresie udrożnienia dróg oddechowych? / How would you rate the level of the qualified first aid (QFA) activities consisting in clearing patient's airway performed by NRFS?

Uwagi: jeżeli w pytaniu 4, 5 lub 9 zaznaczyłaś (-eś) odpowiedź 1 - zaznacz odpowiedź ND (nie dotyczy) / Note: If in questions 4,5 or 9 you have selected answer 1- select answer NA (not applicable)

\begin{tabular}{|c|c|}
\hline Odpowiedzi / Answers & Liczba / Number \\
\hline 1 - niedostatecznie / inadequately & 2 \\
\hline 2 - miernie / poorly & 26 \\
\hline 3 - dostatecznie / enough & 34 \\
\hline 4 - dobrze / good & 25 \\
\hline 5 - bardzo dobrze / very good & 4 \\
\hline 6 - celująco / perfectly & 1 \\
\hline ND / NA - nie dotyczy / not applicable & 6 \\
\hline
\end{tabular}

11. Jak często jednostka KSRG podejmująca czynności w zakresie KPP na miejscu zdarzenia przed przyjazdem ZRM, którego jesteś członkiem stosuje u pacjenta tlenoterapię? / How often does the NRFS unit undertaking QFA activities at the scene before the arrival of MRU you're a member of provide oxygen therapy to a patient?

Uwagi: jeżeli w pytaniu 4 lub 5 zaznaczyłaś (-eś) odpowiedź 1 - zaznacz odpowiedź ND (nie dotyczy) / Note: If in question 4 or 5, you have selected answer 1 - select the answer NA (not applicable)

\begin{tabular}{|c|c|}
\hline Odpowiedzi / Answers & Liczba / Number \\
\hline 1- wcale / not at all & 1 \\
\hline 2- bardzo rzadko / very rare & 14 \\
\hline 3- rzadko / rarely & 15 \\
\hline 4- często / often & 27 \\
\hline 5-bardzo często / very often & 25 \\
\hline 6- zawsze / always & 13 \\
\hline ND / NA- nie dotyczy / not applicable & 3 \\
\hline
\end{tabular}

12. Jak oceniasz poziom wykonywanych czynności KPP przez jednostkę KSRG w zakresie stosowania tlenoterapii? / How would you rate the level of the oxygen therapy QFA activities performed by the NFRS units?

Uwagi: jeżeli w pytaniu 4, 5 lub 11 zaznaczyłaś (-eś) odpowiedź 1 - zaznacz odpowiedź ND (nie dotyczy) / Note: If in questions 4,5 or 11 you have selected answer 1 - select the answer NA (not applicable)

\begin{tabular}{|c|c|}
\hline Odpowiedzi / Answers & Liczba / Number \\
\hline 1 - niedostatecznie / inadequately & 0 \\
\hline 2 - miernie / poorly & 13 \\
\hline 3 - dostatecznie / enough & 24 \\
\hline 4 - dobrze / good & 36 \\
\hline 5 - bardzo dobrze / very good & 19 \\
\hline 6 - celująco / perfectly & 2 \\
\hline ND / NA - nie dotyczy / not applicable & 4 \\
\hline
\end{tabular}

13. Jak często jednostka KSRG podejmująca czynności $\mathrm{w}$ zakresie KPP na miejscu zdarzenia przed przyjazdem ZRM, którego jesteś członkiem stosuje u pacjenta pozycje ułożeniowe? / How often does the NFRS unit undertaking activities in the scope of QFA at the scene, before the arrival of MRU (you are a member of) apply the postural positions?

Uwagi: jeżeli w pytaniu 4 lub 5 zaznaczyłaś (-eś) odpowiedź 1 - zaznacz odpowiedź ND (nie dotyczy) / Note: If in questions 4 or 5 you have selected the answer no. 1- select the answer NA (not applicable) 


\begin{tabular}{|c|c|}
\hline Odpowiedzi / Answers & Liczba / Number \\
\hline 1- wcale / not at all & 6 \\
\hline 2- bardzo rzadko / very rare & 18 \\
\hline 3- rzadko / rarely & 26 \\
\hline 4- często / often & 30 \\
\hline 5-bardzo często / very often & 10 \\
\hline 6- zawsze / always & 5 \\
\hline ND / NA- nie dotyczy / not applicable & 3 \\
\hline
\end{tabular}

14. Jak oceniasz poziom wykonywanych czynności KPP przez jednostkę KSRG w zakresie stosowania pozycji ułożeniowych? / How would you rate the level of QFA activities performed by the NFRS in the application of postural positions?

Uwagi: jeżeli w pytaniu 4, 5 lub 13 zaznaczyłaś (-eś) odpowiedź 1 - zaznacz odpowiedź ND (nie dotyczy) / Note: If in questions 4,5 or 13 you have selected the answer no. 1select the answer NA (not applicable)

Odpowiedzi / Answers

1 - niedostatecznie / inadequately

2 - miernie / poorly

3 - dostatecznie / enough

4 - dobrze / good

5 - bardzo dobrze / very good

6 - celująco / perfectly

ND / NA - nie dotyczy / not applicable

15. Jak często jednostka KSRG podejmująca czynności w zakresie KPP na miejscu zdarzenia przed przyjazdem ZRM, którego jesteś członkiem, stosuje u pacjenta zabezpieczenie termiczne? / How often does the NRFS unit undertaking activities in the scope of QFA at the scene before the arrival your MRU team provide thermal protection to a patient?

Uwagi: jeżeli w pytaniu 4 lub 5 zaznaczyłaś (-eś) odpowiedź 1 - zaznacz odpowiedź ND (nie dotyczy) / Note: If in questions 4 or 5 you have selected answer 1- select the answer NA (not applicable)

\begin{tabular}{|c|c|}
\hline Odpowiedzi / Answers & Liczba / Number \\
\hline 1 - wcale / not at all & 1 \\
\hline 2 - bardzo rzadko / very rare & 9 \\
\hline 3 - rzadko / rarely & 17 \\
\hline 4 - często / often & 37 \\
\hline 5 -bardzo często / very often & 23 \\
\hline 6 - zawsze / always & 8 \\
\hline ND / NA - nie dotyczy / not applicable & 3 \\
\hline \multicolumn{2}{|c|}{$\begin{array}{l}\text { 16. Jak oceniasz poziom wykonywanych czynności KPP przez } \\
\text { jednostke KSRG w zakresie zabezpieczenia termicznego? / } \\
\text { How would you rate the level of the QFA performed by the } \\
\text { NRFS in the aspect of providing thermal protection? }\end{array}$} \\
\hline \multicolumn{2}{|c|}{$\begin{array}{l}\text { Uwagi: jeżeli w pytaniu } 4,5 \text { lub } 15 \text { zaznaczyłaś (-eś) } \\
\text { odpowiedź } 1-\text { zaznacz odpowiedź ND (nie dotyczy) / Note: } \\
\text { If in questions } 4,5 \text { or } 15 \text { you have selected the answer no. } \\
1 \text { - select the answer NA (not applicable) }\end{array}$} \\
\hline Odpowiedzi / Answers & Liczba / Number \\
\hline 1 - niedostatecznie / inadequately & 1 \\
\hline $2-$ miernie / poorly & 13 \\
\hline 3 - dostatecznie / enough & 16 \\
\hline 4 - dobrze / good & 32 \\
\hline 5 - bardzo dobrze / very good & 25 \\
\hline 6 - celująco / perfectly & 7 \\
\hline ND / NA - nie dotyczy / not applicable & 4 \\
\hline
\end{tabular}

Ostatnie pytania zawarte $\mathrm{w}$ ankiecie dotyczyły realizacji pozostałych, wybranych czynności z zakresu KPP przez ratowników jednostek KSRG i podobnie jak we wcześniejszych pytaniach - wraz z próbą oceny jakościowej wykonania tych czynności (tabela 4).

Tabela 4.

Pytania i odpowiedzi do ankiety - od pytania 17 do 22

Table 4.

The survey questions and answers - questions 17-22

17. Jak często jednostka KSRG podejmująca adekwatne czynności $\mathrm{w}$ zakresie KPP na miejscu zdarzenia przed przyjazdem ZRM, którego jesteś członkiem, stosuje u pacjenta unieruchomienia kończyn? / How often does the NRFS unit undertaking appropriate action in the scope of QFA at the scene before the arrival the MRU that you are a member perform in the course of treatment limbs immobilization?

Uwagi: jeżeli w pytaniu 4 lub 5 zaznaczyłaś (-eś) odpowiedź 1 - zaznacz odpowiedź ND (nie dotyczy) / Note: If questions 4 or 5 you have selected the answer no. 1- select the answer NA (not applicable)

\begin{tabular}{|c|c|}
\hline Odpowiedzi / Answers & Liczba / Number \\
\hline 1- wcale / not at all & 13 \\
\hline 2- bardzo rzadko / very rare & 17 \\
\hline 3- rzadko / rarely & 30 \\
\hline 4- często / often & 25 \\
\hline 5-bardzo często / very often & 8 \\
\hline 6- zawsze / always & 2 \\
\hline ND / NA- nie dotyczy / not applicable & 3 \\
\hline
\end{tabular}

18. Jak oceniasz poziom wykonywanych czynności KPP przez jednostkę KSRG w zakresie unieruchomienia kończyn? / How would you rate the level of the QFA actions related to limbs immobilization carried out by the NRFS unit?

Uwagi: jeżeli w pytaniu 4, 5 lub 17 zaznaczyłaś (-eś) odpowiedź 1 - zaznacz odpowiedź ND (nie dotyczy) / Note: If in questions 4, 5 or 17 you have selected the answer no. 1select the answer NA (not applicable)

$$
\text { Odpowiedzi / Answers }
$$

Liczba / Number

1 - niedostatecznie / inadequately

$$
2 \text { - miernie / poorly }
$$

3

3 - dostatecznie / enough 15 4 - dobrze / good

26

5 - bardzo dobrze / very good 30

$$
6 \text { - celująco / perfectly }
$$

ND / NA - nie dotyczy / not applicable

19. Jak często jednostka KSRG podejmująca adekwatne czynności $\mathrm{w}$ zakresie KPP na miejscu zdarzenia przed przyjazdem ZRM, którego jesteś członkiem, stosuje u pacjenta stabilizację kręgosłupa za pomocą deski ortopedycznej z wykorzystaniem pasów oraz stabilizatorów głowy $\mathrm{z}$ jednoczesnym zastosowaniem stabilizacji odcinka szyjnego kregosłupa za pomocą kołnierza ortopedycznego? / How often does the NRFS unit undertaking an appropriate QFA action at the scene before the arrival of your MRU team use the stabilization of the spine with orthopedic boards using belts and stabilizers of the head with the combined stabilization of the cervical spine with neck brace in their patients treatment?

Uwagi: jeżeli w pytaniu 4 lub 5 zaznaczyłaś (-eś) odpowiedź 1 - zaznacz odpowiedź ND (nie dotyczy) / Note: If in questions 4 or 5 you have selected the answer no. 1- select the answer NA (not applicable)

\begin{tabular}{|c|c|}
\hline Odpowiedzi / Answers & Liczba / Number \\
\hline 1- wcale / not at all & 1 \\
\hline 2- bardzo rzadko / very rare & 7 \\
\hline 3- rzadko / rarely & 15 \\
\hline
\end{tabular}




\begin{tabular}{|c|c|}
\hline 4- często / often & 25 \\
\hline 5-bardzo często / very often & 32 \\
\hline 6- zawsze / always & 15 \\
\hline ND / NA- nie dotyczy / not applicable & 3 \\
\hline
\end{tabular}

20. Jak oceniasz poziom wykonywanych czynności KPP przez jednostkę KSRG w zakresie unieruchomienia na desce ortopedycznej? / How would you rate the level of KPP activities carried out by the NRFS unit in the field of orthopedic immobilization on the board?

Uwagi: jeżeli w pytaniu 4, 5 lub 19 zaznaczyłaś (-eś) odpowiedź 1 - zaznacz odpowiedź ND (nie dotyczy) / Note: If in questions 4,5 or 19 you have selected the answer no. 1select the answer NA (not applicable)

\begin{tabular}{|c|c|}
\hline Odpowiedzi / Answers & Liczba / Number \\
\hline 1 - niedostatecznie / inadequately & 0 \\
\hline 2 - miernie / poorly & 13 \\
\hline 3 - dostatecznie / enough & 24 \\
4 - dobrze / good & 31 \\
\hline 5 - bardzo dobrze / very good & 21 \\
\hline 6 - celująco / perfectly & 5 \\
\hline ND / NA - nie dotyczy / not applicable & 4 \\
\hline
\end{tabular}

21. Jak często jednostka KSRG podejmująca adekwatne czynności w zakresie KPP na miejscu zdarzenia przed przyjazdem ZRM, którego jesteś członkiem, stosuje u pacjenta RKO? / How often does the NRFS unit, which is undertaking an appropriate qualified first aid action at the scene before the arrival of MRU you are a member, perform the cardiopulmonary resuscitation on a patient?

Uwagi: jeżeli w pytaniu 4 lub 5 zaznaczyłaś (-eś) odpowiedź

1 - zaznacz odpowiedź ND (nie dotyczy) / Note: If in the question 4 or 5 you have selected the answer no. 1- select the answer NA (not applicable)

\begin{tabular}{|c|c|}
\hline Odpowiedzi / Answers & Liczba / Number \\
\hline 1- wcale / not at all & 6 \\
\hline 2- bardzo rzadko / very rare & 14 \\
\hline 3- rzadko / rarely & 18 \\
\hline 4- często / often & 27 \\
\hline 5-bardzo często / very often & 11 \\
\hline 6- zawsze / always & 19 \\
\hline ND / NA- nie dotyczy / not applicable & 3 \\
\hline
\end{tabular}

22. Jak oceniasz poziom wykonywanych czynności KPP przez jednostkę KSRG w zakresie RKO? / How would you rate the level of cardiopulmonary resuscitation carried out by the NRFS unit?

Uwagi: jeżeli w pytaniu 4, 5 lub 21 zaznaczyłaś (-eś) odpowiedź 1 - zaznacz odpowiedź ND (nie dotyczy) / Note: If in questions 4,5 or 21 you have selected the answer no. 1 select the answer NA (not applicable)

Odpowiedzi / Answers

1 - niedostatecznie / inadequately 2 - miernie / poorly

3 - dostatecznie / enough 4 - dobrze / good

5 - bardzo dobrze / very good 6 - celująco / perfectly

ND / NA - nie dotyczy / not applicable

\begin{tabular}{|c|}
\hline Liczba / Number \\
\hline 2 \\
\hline 9 \\
\hline 31 \\
\hline 33 \\
\hline 13 \\
\hline 1 \\
\hline 9
\end{tabular}

Wykresy przedstawione na ryc. 7 i 8 obrazują wyniki zawarte $w$ tabelach 3 i 4 . Ankietowani uznali, iż w większości przypadków ratownicy rzadko (odp. 3) stosują u poszkodowanych udrożnienie dróg oddechowych (pytanie nr 9) i jednocześnie wykonują tę czynność na poziomie dostatecznym (odp. 3).

$31,58 \%$ ankietowanych wskazało, że ratownicy rzadko (odp. 3) wykonują unieruchomienie kończyn (pytanie nr 17), przy czym ocena jakościowa tej czynności w większości wypadła na poziomie dobrym (odp. 4). Warto jednak zauważyć, iż 13,68\% respondentów stwierdziło, że strażacy wcale (odp. 1), a 17,89\%, że bardzo rzadko (odp. 2) wykonują unieruchomienia kończyn.

Stosowanie tlenoterapii $(28,42 \%)$, pozycji ułożeniowych $(31,58 \%)$, zabezpieczenie termiczne $(38,95 \%$ - najwyższa wartość) oraz RKO $(28,425 \%)$ oceniono najwyżej na poziomie wykonywania 4 (często). Jednocześnie strażacy wykonują te czynności na poziomie dobrym (odp. 4 w 6-cio stopniowej skali). Najwięcej osób wysoko oceniło w tej grupie jakość stosowania tlenoterapii - na poziomie $38,30 \%$.

Bardzo często (odp. 5) według oceny respondentów, z udziałem procentowym $33,68 \%$, ratownicy wykonują unieruchomienie na desce ortopedycznej. Natomiast 26,32\% osób uważa, że często - odp. 4 (pytanie nr 19). $\mathrm{Z}$ udzielonych odpowiedzi wynika, że 32,98\% ankietowanych uznała poziom stosowania unieruchomienia na desce ortopedycznej jako dobry (odp. 4), a 25,53\% jako dostateczny (odp. 3).

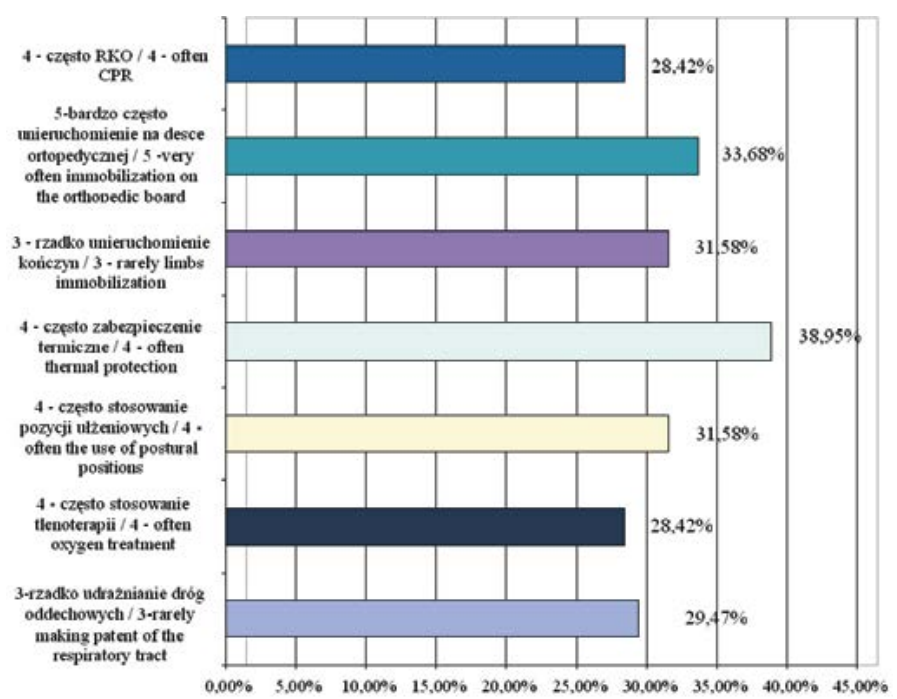

Ryc. 7. Porównanie wyników odpowiedzi zawartych w tabeli 3 Fig. 7. The comparison of results in table 3

4-dobrze RKO / 4-good CPR

4-dobrze unienchomienie na desce ortopedycznej / 4-good immobilization on the orthopedic board

4-dobrze unienuchomienie konczyn / 4-good limbs immobilization

4-dobrze zabezpieczenie termiczne / 4-good thermal protection

4-dobrze stosowanie pozycji ułożeniowych / 4-good the use of postural positions

4-dobrze stosowanie tlenoterapii / 4 -good oxygen treatment

3- dostatecznie udrożnianie dróg oddechowych / 3- enough making patent of the respiratory tract

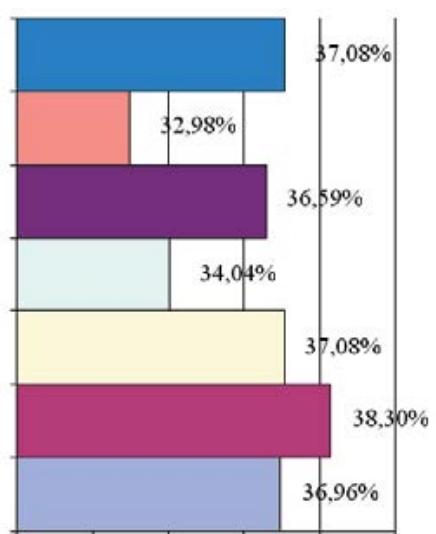

$30,00 \% 32,00 \% 34,00 \% 36,00 \% 38,00 \% 40,00 \%$

Ryc. 8. Porównanie wyników odpowiedzi zawartych w tabeli 4 Fig. 8. The comparison of results in table 4 
Ryciny 9 i 10 przedstawiają procentowy rozkład odpowiedzi udzielonych na pytania dotyczące RKO. Pomimo że najwięcej osób wysoko oceniło podejmowanie przez jednostki KSRG adekwatnych czynności w zakresie KPP na miejscu zdarzenia przed przyjazdem ZRM, uznając, że stosują u pacjenta RKO często (odp. 4), to w sumie $40 \%$ ankietowanych oceniło częstość podejmowania RKO u pacjentów poniżej tej oceny - w tym $6,32 \%$ ankietowanych uznało, że RKO nie jest w ogóle podejmowana. Najwięcej respondentów wskazało, że RKO wykonywana jest na poziomie dobrym (odp. 4), niemal 35\% kolejnych uznało, że jest to już poziom dostateczny (odp. 3).

21. Jak często jednostka KSRG podejmująca adekwatne czynności w zakresie KPP na miejscu zdarzenia przed przyjazdem ZRM, którego jesteś członkiem stosuje u pacjenta RKO? How often does the KSRG unit which is undertaking an appropriate qualified first aid action at the scene before the arrival of ZRM you are a member of perform the cardiopulmonary resuscitation on a patient?

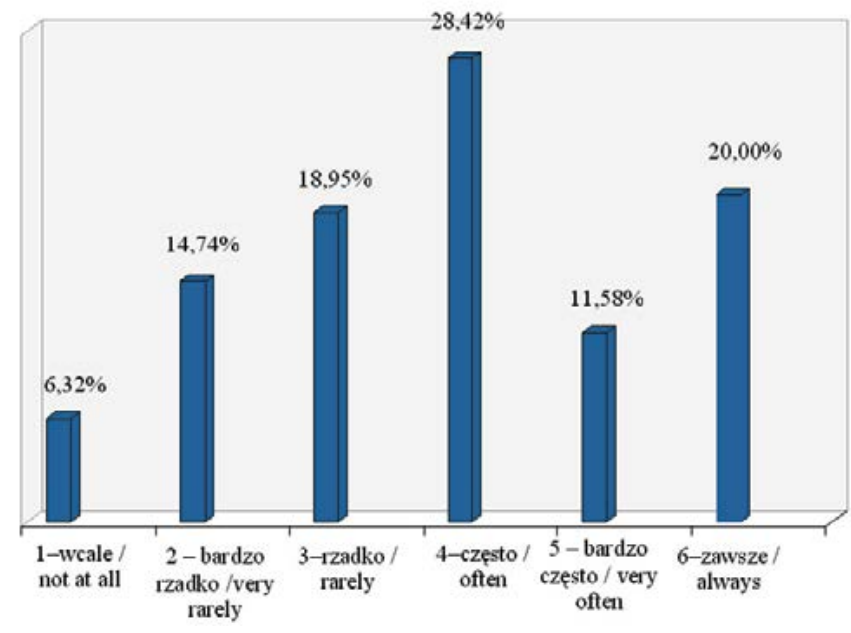

22. Jak oceniasz poziom wykonywanych czynności KPP przez jednostkę KSRG w zakresie RKO? / How would you rate the level of CPR carried out by the NRFS unit?

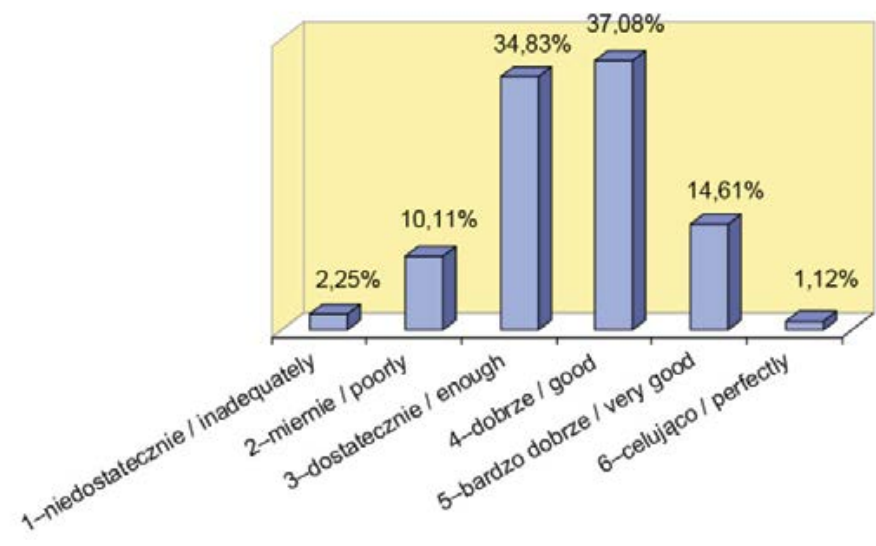

Ryc. 9, 10. Procentowy rozkład udzielonych odpowiedzi na pytania dotyczące resuscytacji krążeniowo-oddechowej

Fig. 9, 10. The answers percentage about CPR

\section{Podsumowanie wyników}

Celem przeprowadzenia ankiety było zbadanie poziomu udzielania KPP przez jednostki KSRG oraz ocena zaangażowania jednostek KSRG w udzielanie KPP.
W ankiecie zapytano między innymi o to, jak często przed przyjazdem ZRM jednostka KSRG jest już na miejscu zdarzenia. Ponad połowa ankietowanych wskazała, że często, a $1 / 5$, że bardzo często. Wobec podanych wcześniej czasów dojazdów ZRM i jednostek KSRG potwierdza się założenie, że w większości przypadków (zwłaszcza poza obszarami dużych aglomeracji miejskich) jednostki KSRG będą w pierwszej kolejności na miejscu zdarzenia, przed pogotowiem ratunkowym.

Blisko połowa respondentów uznała, że jednostki włączone do KSRG zawsze wymieniają deski ortopedyczne z ZRM (w przypadku użycia swojej dla pacjenta), stosując tym samym zasadę, ,jednych noszy". Może to świadczyć o zwiększonej świadomości znaczenia podstawowych standardów ratownictwa medycznego. Wymiana sprzętu medycznego między służbami czy samymi zespołami, choć w sposób oczywisty korzystna dla pacjentów, nie jest jeszcze powszechna.

Wyniki ankiety wskazują, iż zaangażowanie jednostek KSRG w pomoc zespołom systemu PRM jest znacząca. Równie istotna jest także świadomość wagi podejmowanych przez ratowników KSRG działań.

Ankietowani uznali, iż w większości przypadków ratownicy rzadko stosują u poszkodowanych udrożnienie dróg oddechowych i jednocześnie wykonują tę czynność na poziomie dostatecznym. Biorąc pod uwagę, iż samo udrożnienie dróg oddechowych jest podstawowym elementem oceny parametrów życiowych pacjenta, wyniki są niepokojące.

Grupa czynności takich jak: stosowanie tlenoterapii, stosowanie pozycji ułożeniowych, zabezpieczenie termiczne oraz RKO została ogólnie oceniona przez respondentów dobrze w zakresie częstości podejmowania działań, jak również samej oceny jakościowej.

W zakresie unieruchomienia na desce ortopedycznej wyniki ankiety nasuwają wniosek, iż ratownicy KSRG bardzo chętnie stosują stabilizację kręgosłupa za pomocą deski ortopedycznej z wykorzystaniem pasów oraz stabilizatorów głowy $\mathrm{z}$ jednoczesnym zastosowaniem stabilizacji odcinka szyjnego kręgosłupa za pomocą kołnierza ortopedycznego. Jednakże w ocenie respondentów poziom wykonania tych czynności nie jest celujący ani bardzo dobry.

Ze względu na rangę wdrażania RKO u osób z nagłym zatrzymaniem krążenia (NZK), warto zastanowić się szczególnie nad wynikami w zakresie podejmowania przez jednostki KSRG resuscytacji krążeniowo-oddechowej. Te wyniki najbardziej zaskakują, gdyż w kształceniu ratowników KPP są to tematy priorytetowe. Właśnie tu spodziewano się najwyższych ocen. Pomimo iż najwięcej osób wysoko oceniło podejmowanie przez jednostki KSRG adekwatnych czynności w zakresie KPP na miejscu zdarzenia przed przyjazdem ZRM, uznając, że stosują u pacjenta RKO często, to blisko połowa ankietowanych oceniła częstość podejmowania RKO u pacjentów poniżej tej oceny - w tym część uznała, że RKO nie jest w ogóle podejmowana. Najwięcej respondentów wskazało, że RKO wykonywana jest na poziomie dobrym, niemal kolejnych $35 \%$ uznało, że jest to już poziom dosta- 
teczny. Zatem ocena jakościowa też nie wypadła najlepiej.

Przed badaniem przeważał pogląd, że ocena poziomu udzielania KPP przez jednostki KSRG oraz zaangażowanie jednostek KSRG w udzielanie KPP będzie na bardzo wysokim lub nawet celującym poziomie. Wyniki pokazują jednak, że tak nie jest. Może na to wpływać dystans zespołów ratownictwa medycznego wobec jednostek KSRG, w tym brak zaufania do stopnia opanowania przez nich zasad KPP. Z drugiej zaś strony może to właśnie ratownikom jednostek KSRG brakuje krytycyzmu w stosunku do swoich umiejętności? Trudno te kwestie rozstrzygnąć jednoznacznie, analiza tego zagadnienia wymaga dalszych szczegółowych badań, niemniej nasuwa się wstępny wniosek - samo odbycie szkolenia nie świadczy o wysokich zdolnościach praktycznych w zakresie KPP. Bez możliwości ćwiczenia i sprawdzania praktycznej znajomości zasad KPP oraz praktycznego wykorzystywania zdobytych umiejętności w codziennych działaniach ratowniczych, zarówno wiedza teoretyczna, jak i praktyczna ratownika staje się mniej wartościowa. Zdaniem autorów w dotychczasowym systemie kształcenia ratowników i późniejszym działaniu zawodowym brakuje elementu utrwalania umiejętności, czyli doskonalenia ustawicznego. Według autorów dopracowania wymagają zasady utrwalania i okresowej kontroli umiejętności po 66-godzinnym kursie KPP, pomimo określonej przepisami recertyfikacji, która odbywa się w cyklach 3-letnich.

\section{Wnioski}

1. Udzielanie przez ratowników KSRG kwalifikowanej pierwszej pomocy osobom znajdującym się w stanie nagłego zagrożenia zdrowotnego przed przybyciem zespołu ratownictwa medycznego zwiększa szanse na przeżycie pacjentów.

2. Szkolenie ratowników KSRG z zakresu KPP wpływa na podniesienie poziomu przygotowania do udzielania pomocy osobom znajdującym się w stanie nagłego zagrożenia zdrowotnego.

3. Należy wprowadzić regulacje prawne umożliwiające dyspozytorowi medycznemu wykorzystanie potencjału KSRG do udzielania KPP przed przybyciem zespołu ratownictwa medycznego.

4. Należy dopracować wymagania dotyczące zasad utrwalania i okresowej kontroli umiejętności po 66-godzinnym kursie KPP, pomimo określonej przepisami recertyfikacji, która odbywa się w cyklach 3-letnich.

\section{Literatura}

1. Analiza potencjalu ratowniczego Ochotniczych Straży Pozarnych wtaczonych do krajowego systemu ratowniczo-gaśniczego, Warszawa, marzec 2011.

2. Craig AM, Verbeek PR, Schwartz B., Evidence-based optimization of urban firefighter first response to emergency medical services 9-1-1 incidents, "Prehosp Emerg Care", Jan-Mar; Vol. 14 Issue 1, 2010, pp. 109-17.

3. Dane statyczne Komendy Głównej PSP. Dane dotyczą pożarów (P) i miejscowych zagrożeń (MZ) za rok 2012.

4. Dane statystyczne Ministerstwa Zdrowia.

5. Dane statystyczne SP ZOZ Lotnicze Pogotowie Ratunkowe.

6. Hu SC, Kao WF, Tsai J, Chern CH, Yen D, Lo HC, Lee CH. Analysis of prehospital ALS cases in a rural community, Zhonghua Yi Xue Za Zhi, „Taipei”, 1996, Vol. 58 Issue 3, 2014, pp. 171-6.

7. Jakubaszko J., Kierunek ratowniczo-medyczny: studia licencjackie pierwszego stopnia, Polskie Towarzystwo Medycyny Ratunkowej, Wrocław, 2007.

8. Rozporządzenie Ministra Spraw Wewnętrznych i Administracji z dnia 18 lutego $2011 \mathrm{r}$. w sprawie szczegółowych zasad ekranizacji krajowego systemu ratowniczo-gaśniczego (Dz. U. z dnia 3 marca 2011 r.)

9. Rozporządzenie Ministra Zdrowia z dnia 19 marca 2007 roku w sprawie kursu w zakresie kwalifikowanej pierwszej pomocy.

10. Smith K., Rich D., Pinol J.P., Hankin J., McNeil J., Acceptance of a medical first-responder role by fire fighters, „Resuscitation", Vol. 51 Issue 1, 2001, pp. 33-8.

11. Sosnowski Z., Odpowiedź podsekretarza stanu w Ministerstwie Spraw Wewnętrznych i Administracji - z upoważnienia prezesa Rady Ministrów - na interpelację nr 21205 w sprawie rozwoju sieci jednostek ochrony przeciwpożarowej w krajowym systemie ratowniczo-gaśniczym, Warszawa, 4 kwietnia $2011 \mathrm{r}$.

12. Ustawa $z$ dnia 8 września 2006 roku o Państwowym Ratownictwie Medycznym (Dz. U. Nr 191, poz. 1410).

13. www.straz.gov.pl [dostęp: 31.12.2012].

14. Zasady organizacji ratownictwa medycznego $w$ krajowym systemie ratowniczo-gaśniczym, Warszawa, 26 lipca $2013 \mathrm{r}$.

15. Zasady organizacji ratownictwa medycznego $w$ krajowym systemie ratowniczo-gaśniczym. Załacznik $n r 3$ Standard wyposażenia podmiotów KSRG $w$ zestawy ratownictwa medycznego, Warszawa, 26 lipca $2013 \mathrm{r}$.

dr n. med. Robert Galązkowski - jest adiunktem w Zakładzie Ratownictwa Medycznego Warszawskiego Uniwersytetu Medycznego.

mgr Agata Pawlak - jest kierownikiem Działu Ratownictwa Medycznego w SP ZOZ Lotnicze Pogotowie Ratunkowe, a także strażakiem OSP Zawady.

dr n. med. Konrad Pszczołowski - jest starszym wykładowcą w Katedrze i Zakładzie Zdrowia Publicznego Warszawskiego Uniwersytetu Medycznego. 